\title{
HINDUTVA AGENDA AND HISTORY WRITING: IMAGININGS OF NATION
}

\author{
Sucheta Mahajan \\ Jawaharlal Nehru University, Delhi
}

\section{Abstract}

This article discusses the ideological and political ramifications of historical interpretation. It examines the communal perspective on the writing of history to show how it is a distorted representation of reality, so institutions propagate the communal point of view and suppress alternative perspectives. The suppression of the textbooks written from a secular scientific standpoint and the distortions in the textbooks for schools sponsored by the communal groups wielding state power are analysed. This need for legitimacy on the part of the communal forces prompts them to appropriate the icons of the secular nationalist movement - clearly a farcical exercise.

Keywords: Communalism, Distortion and appropriation, History writing in India, State power.

\section{RESUMEN}

Este artículo reflexiona sobre las ramificaciones ideológicas y políticas de la interpretación histórica india. Examina los prejuicios sectario-religiosos en la historiografía, que las instituciones utilizan para arrojar una representación distorsionada de la realidad, sin dar cabida a otros puntos de vista. Así, estudiamos cómo se promueven determinados libros de texto y suprimen otros en beneficio de posiciones sectarias. A su vez, estos grupos se apropian de las figuras representativas del nacionalismo laico.

Palabras clave: Comunalismo, Distorsión y apropiación, Historiografía en India, Poder del Estado. 
Hindutva is not a word but a history. Not only the spiritual or religious history of our people as at times it is mistaken to be by being confounded with the other cognate term, Hinduism. Hinduism is only a derivative, a fraction, a part of Hindutva... Hindutva embraces all the departments of thought and activity of the whole being of our Hindu race.

(Savarkar 3-4)

Rewriting of history is to gain legitimation from the past for the political requirements of the present.

(Thapar 2000)

When we speak of the contested imaginings of the nation, history writing is what generally comes to mind. This is the body over which the battle for the minds of the people is fought. The spread of communal ideology is predicated on a certain distorted representation of history.

The two perspectives, communal and secular, espouse narrow, exclusivist conceptions of the nation and broad, inclusive ones respectively. The contest is not only about history, its practice, professional or otherwise. It is on the terrain of the idea of the nation and it is waged by citizens with a stake in the kind of country they want their children to grow up in.

In this article, I propose to discuss the communal interpretation of history, its popularization in textbooks written for Rashtriya Swayamsevak Sangh (RSS) schools and National Council of Educational Research and Training (NCERT), the undermining of secular and scientific history and the use of state power to control educational and research bodies and suppress alternative points of view.

The glorification of India's ancient Hindu past goes back to the nineteenth century. The communal interpretation of history is, at its very basis, colonial. Communal historiography followed colonial writers in its division of Indian history into a glorious ancient Hindu past, a decadent Muslim period and a beneficial British period.In this worldview, India's ancient civilization was deemed to be as old as the ancient Greeks and Romans, superior to them and even its progenitor.

V.D. Savarkar's Hindutva —or Who is a Hindu? ([1923] 1989) defined Pitribhumi (land of ancestors) and punyabhumi (sacred land) in such a way that it has no place for Muslims and Christians (Bhatt 99). Savarkar highlighted the foreign invasions in Indian history, especially by Muslims. British rule was seen as benign, in comparison with Mughal rule, a period of ruthless oppression of Hindus (Bhatt 53). Savarkar's Hindutva ([1923] 1989) and Swami Shraddhanand's Hindu Sangathan - Saviour of a Dying Race (1926), both written during a mass anti-colonial movement, were silent on the movement and on colonialism (Bhatt 41).

This perception continued with Golwalkar, the head of the RSS. In Bunch of Thoughts (1966), he wrote: "Their [Muslims'] history of the past one thousand two hundred years, full of incidents of destruction, depredation, all sorts of barbaric atrocities, is there before our eyes. The present day large Muslim population in our 
country is one of the results of the fatal devastation that they wrought all over the land... What has our good behaviour towards the Muslim faith and the Muslim people brought us? Nothing but desecration of our holy places and enslavement of our people" (Golwalkar 1966: 294-295).

Let us look at the Hindutva history and its popularization in RSS schools, such as Shishu Mandirs and Vidya Bharati schools.

In this view, 'Aryans' were the true Indians, whose origin is in India. Hence, Golwalkar came up with the startling theory that "the Arctic Home in the Vedas was verily in Hindusthan itself and that it was not the Hindus who migrated to that land but the Arctic which emigrated and left the Hindus in Hindusthan" (Gowalkar 1939: 11-13) .Buddhism, rather than Islam, is the first target. In particular, the propagation of non violence by the Mauryan king, Ashoka, is alleged to have spread cowardice in the land. Later, Muslims became the target. They were described as "hissing Yavana snakes," who had to be destroyed (Bhishikar 41).

The BJP's forming the government at the Centre in 1999 and in 2014, encouraged the RSS and the Akhil Bhartiya Itihas Sankalan Samiti (All India History Compilation Committee) in their attempts to communalize the writing of history. The aim of the Samiti is to rewrite the history of India from a "national" perspective. It claimed that places like the Vatican, Westminster Abbey, and similarly iconic structures around the world, including the Taj Mahal, were actually temples of Shiva and that Christianity and Islam are derivatives of Hinduism ("Allow" 2017)

The Bharatiya Shikshan Mandal was set up in 1969 to promote the RSS' aim of introducing 'eternal Bharatiya values' in the education system, rewriting school and university textbooks to provide a 'history of the Indian Freedom Struggle' against 'foreign invaders [over] the last 2,500 years', and making Sanskrit teaching compulsory (Bharatiya 2017)

The rapidly growing influence of the RSS institutions spreading such hatred and poison is a matter of concern (Sundar 2004). The Saraswati Shishu Mandirs go back to 1952. By 1977, there were already about 500 RSS schools and 20,000 students. Vidya Bharati was formed that year, in line with RSS Hindutva ideology and in opposition to Christian-run schools (Bhatt 114). Vidya Bharati schools were encouraged during periods of BJP rule in the states and given licence to frame their syllabi. By 1993-94 the total number of schools run by Vidya Bharati was 6,000 with 40,000 teachers and 1,200,000 students. With BJP in power at the centre in 1998, the RSS influence in schools spread rapidly. In 1999 there were 14,000 Vidya Bharati schools with 80,000 teachers and 1,800,000 students! (Kanungo 2002; Goyal 2000).

A National Steering Committee on Textbook Evaluation (1993-94), consisting of historians Bipan Chandra, Ravinder Kumar and Arjun Dev, among others, examined the textbooks used in the schools run by the RSS and published by the Saraswati Shishu Mandir Prakashan and Vidya Bharati Publications. The Com- 
mittee concluded that the textbooks in question claimed to instil patriotism but instead ended up promoting a virulent communal view of Indian history, bigotry and fanaticism. The books are dismissive of historical facts, which they tailor to suit their point of view.

The Committee advised that publications of Saraswati Shishu Mandir Prakashan and those in use in Vidya Bharati schools not be allowed to be used in schools. This was because of their pernicious content. On Ashoka, the Gaurav Gatha said that "Ahimsa began to be ... advocated. Every kind of violence began to be considered a crime. Even hunting, sacrifices in yajnas and use of arms began to be considered bad... Cowardice slowly spread throughout the kingdom. [...] Soldiers guarding the borders were demoralized... The preaching of Ahimsa had weakened north India." On Islam it was said that "Wherever they went, they had a sword in their hand. Their army went like a storm in all the four directions. Any country that came their way was destroyed. Houses of prayers and universities were destroyed. [...] Religious books were destroyed. Mothers and sisters were humiliated. Mercy and justice were unknown to them." We are told that "Delhi's Qutb Minar... was actually built by emperor Samudragupta. Its real name was Vishnu Stambha... This Sultan actually got some parts of it demolished and its name was changed" ("Gaurav" 30-31, 51-52). A textbook for Class V added the Quran to the sword as a weapon in the armoury of the invaders. Forcible conversion was decried, and it was lamented that reconversion to Hinduism could not be achieved ("Itihas" 3).

The tenor of the booklet on other religions and their founders was dismissive. In the case of Christians, they were dubbed as anti-national. The responsibility for the partition of India was laid squarely at their door. The mischief did not end there; missionaries, it was alleged, continued to work in sensitive areas such as the North East, spreading anti-national sentiments a mong the people they worked with. In a question-answer format that students were expected to memorise, the answer given to the question, how did Prophet Mohammad spread Islam, was, "rivers of blood" (Mahajan et al. 27). The raison d'etre of the RSS is couched in divine origins. We are told that, just as Bhagwan Krishna emerged for the preservation of Indian culture, the RSS has arisen to defend the greatness of Bharatiya Sanskriti, Indian culture (Mahajan et al. 28).

In Gujarat the state-sponsored textbooks came in for sharp criticism for their praise of fascism. The Gujarat State Social Studies' textbook for Std. X approvingly cited Hitler's description of Germans as the only pure Aryans in the entire world... who were born to rule the world'. Under the head, "Internal Achievements of Nazism", was written, "Hitler lent dignity and prestige to the German government within a short time by establishing a strong administrative set up... He adopted the policy of opposition towards the Jewish people and advocated the supremacy of the German race" ("Demonising” 1999; “On Fascism” 1999). 
In this section let us take a look at the determined effort by communal forces to undermine scientific and secular history, in order to create the ground for the rewriting of history. State power was used to attack history and historians espousing a left, liberal standpoint and to prevent the publication of history books which do not conform to Hindutva ideology.

The influence of RSS increased when the Jan Sangh became a part of the Janata Party and the government in 1977. A ban was proposed on school textbooks written for NCERT by historians Romila Thapar, R.S. Sharma, Satish Chandra, Bipan Chandra and Arjun Dev. The National Integration Council had charged these authors with the task of writing history books which were free from communal prejudice and colonial distortion. This proposed ban sparked widespread protest. As young students of the Centre for Historical Studies, Jawaharlal Nehru University, we joined the protest against this gagging of the secular NCERT history textbooks. I recall going for a big meeting at the Delhi School of Economics, reported in the press as busloads being brought in from Jawaharlal Nehru University.

A second attempt at a ban was when the BJP came to power at the centre in the late 1990s. The government carefully selected men who would do its bidding as heads the NCERT, University Grants Commission (UGC), Indian Council for Historical Research (ICHR) and the Indian Council for Social Science Research (ICSSR). Murli Manohar Joshi, a trusted RSS man, was made the Minister for Education, so that the government agenda in the key area of education could be implemented on a priority basis. M.M. Joshi lost no time in ushering in a new National Curriculum Framework (NCF) in 2000. The lack of consultation, particularly with the states - who were equally responsible as the Centre for education, it being a concurrent subject- was in violation of norms (Mahajan et al. 32-33).

On the bidding of the RSS, passages were deleted from the NCERT history books. Dina Nath Batra, the General Secretary of Vidya Bharati and head of the Shiksha Sanskriti Utthan Nyas (Trust for the Uplift of Education and Culture) and the Shiksha Bachao Andolan Samiti (Committee for the Save Education Movement), published The Enemies of Indianisation: The Children of Marx, Macaulay and Madarsa, on 15 August 2001. The book listed 41 distortions in the existing NCERT books (Mahajan et al. 2008: 33-34).

A wide section of the Indian intelligentsia protested (Mukherjee and Mukherjee 2002) Giving a veto over what goes into textbooks to religious leaders effectively means that no research can be done in a scientific way. One dreads to think of the impact on young minds if the content of their courses is altered by religious leaders.

Hindu communal forces were quick to brand those who did not agree with their interpretations as anti-national. The RSS Sarvasanghachalak, K.S. Sudershan, 
called them 'anti-Hindu Euro-Indians', who hated 'Vedic maths' and did not believe that in ancient India we knew about nuclear energy and aeroplanes. ${ }^{1}$

Calls were made for the arrests of historians Romila Thapar, R.S. Sharma and Arjun Dev. Murli Manohar Joshi defended the deletions from their books and called for a war for the country's cultural freedom.

Despite nationwide protests, this 'Talibanisation' of education continued. A new syllabus based on the NCF 2000 was adopted, again without proper procedures being followed. The existing NCERT history books were withdrawn and replaced by books written not by experts but by authors close to the Sangh ideology. ${ }^{2}$ As Thapar reminds us, "There is no recognition of the technical training required of historians and archaeologists" (Thapar 2000).

The Indian History Congress volume, History in the New NCERT Text Books: A Report and an Index of Errors pointed out that the errors stem from an anxiety to present history with a communal bias. The textbooks drew heavily on the propaganda by the Sangh, as the following statements of the new NCERT Text Books show. India was deemed to be the original home of the Aryans. The 'Vedic Civilization' was placed further back in time than professional historians have. The Vedic civilization was declared to cover the Indus Civilization, now to be called 'Indus Saraswati' civilization. It is claimed that all scientific discoveries from zero to decimal placement of numerals to heliocentric astronomy were made in the 'Vedic Civilization'. The Hindu religion was superior to other religions. The Upanishads were declared as 'the most profound works of philosophy in any religion'. Hindus, moreover, were true patriots. In the freedom struggle against the British, they alone were sincere, while the Muslims dreamt of an empire or a separate nation. Practices such as sati or jauhar were approved of as were abductions of women, which were even described as a legitimate form of marriage. Coming to the modern period, Hindu Mahasabha (HM) leaders are depicted as great patriots whereas the villain of the piece is Muslim separatism. The Hindu social reformers, Ram Mohan Roy, Keshav Chandra Sen, JotibaPhule, and B.R. Ambedkar are ignored. The reason perhaps is the belief that Hindu society did not need reform. Jawaharlal Nehru, the Left, and the Communists were ignored, for other reasons.

The History Congress report concluded that no degree of modification could make the RSS -inspired textbooks passable. The only option was withdrawal. Of course, this had to wait till the regime was voted out of power.

1 Sage Bharadwaja and Raja Bhoj not only 'described the construction of Aeroplanes' but discussed 'details like what types of aeroplanes would fly at what height, what kind of problems they might encounter, how to overcome those problems, etc'.

2 These included textbooks by Makkhan Lal, Meenakshi Jain and Hari Om. 
Increasingly, members of the RSS have been appointed to head premier research and academic bodies, and RSS-minded organizations have come to control education and determine the contours of academic space. The Indian Council of Historical Research was reconstituted in 2015 with members distinguished by little except their ideological affinity with the RSS. The agenda adopted included establishing the historicity of the epics and proving the existence of the Ram temple at Ayodhya at the contested site of the Babri Masjid, which was destroyed by members of Hindu communal organizations in 1992.

The ICHR Foundation Day lecture in 2015 was given by David Frawley on 'Textual Evidence in Vedas - Cultural and Historical Implications'. Frawley, whose Indian name is Vamdev Shastri, is an American-Hindu spiritual teacher and a strong proponent of yoga, Vedic astrology and ayurveda. As Thapar puts it "Engineers, computer experts, journalists-turned-politicians, foreign journalists posing as scholars of Indology, and what have you, assume infallibility, and pronounce on archaeology and history" (2000). Historicity of Ramayana and Mahabharata is the special interest of the Council, as is the Ram Setu, for which marine archaeology is commandeered to the cause (Pandey 2017).

The "Towards Freedom" series of the ICHR attracted the ire of the Hindu communalists who were not part of the tryst with freedom. In December 1999, the volumes on 1940 and 1946, edited by K.N. Panikkar and Sumit Sarkar, approved by the general editor and already in press, were called back during the tenure of the National Democratic Alliance (NDA) regime between 1999 and 2004. Allegations of large expenditure and delays were levelled at the "Towards Freedom" project by the Bharatiya Janata Party ideologues Murli Manohar Joshi and Arun Shourie. An "expert committee," whose members singularly lacked expertise in modern Indian history, was formed to review the books. K.N. Panikkar, editor of the 1940 volume, hinted that behind the cancellation was BJP anxiety that the volumes would expose its predecessors, the RSS and the HM, as having collaborated with the British. (Interview with K.N. Panikkar in Frontline, 17/5, March, 04, 2000. Nd). "Towards Freedom" was shut down, violating academic freedom and institutional autonomy (Media Statement by Professor S. Gopal in "Fascist" 2000).

Some recent incidents of censorship have been aimed to discredit liberal and progressive historiography, in order to prepare the ground for the Hindu communalist project of rewriting of history.

The first episode concerns The Hindus: An Alternative History (2009), a much celebrated book by Wendy Doniger. Dina Nath Batra, head of various RSS education outfits, demanded that it be be banned. The publisher, Penguin Books, a multinational giant, chose to pulp the book rather than take on Batra ("Penguin" 2014).

The second pertained to a two - pronged attack, in Parliament and in the media, on India's Struggle for Independence, published in 1988. Bipan Chandra was charged with denigrating Bhagat Singh by describing him as a 'terrorist'. In fact the first time the term 'revolutionary terrorism' is used in the book, Bipan Chandra clearly said that it is "a term we use without any pejorative meaning and for want 
of a different term." In his later writings, Bipan Chandra dropped this term as the word terrorism had acquired a very negative meaning. The authors removed the term revolutionary terrorists, as Bipan Chandra intended to do, yet a case was filed at a Kanpur court charging authors with 'criminal defamation', 'criminal intimidation', 'intentional insult with intent to provoke breach of peace' and 'criminal conspiracy'.

In a third episode, in September 2016, National Book Trust revoked the reprint order for the Hindi edition of Bipan Chandra's book, Communalism - a Primer. The book had been the rallying point around which an ideological campaign against communalization of education was launched. The attack was not surprising given that Bipan Chandra was not only an eminent historian, but one who upheld the core values of the freedom struggle and the secular polity that followed it. The new Chairman of National Book Trust is, not coincidentally, a former editor of Panchjanya, a mouthpiece of the RSS ("Former" 2015).

The communal rewriting of our history results in a complete inversion. In the NCERT textbooks sponsored by the RSS, the role of the Mahatma is underplayed and the role of the Hindu communal groups in his assassination glossed over. Hari Om's Contemporary India for Class X quietly sidestepped Gandhiji's assassination. When there was a nationwide controversy on this question, the relevant sentence was modified thus:

Gandhiji's efforts to bring peace and harmony in society came to a sudden and tragic end due to his assassination by Nathuram Godse on January 30 1948, in Delhi while Gandhiji was on his way to attend a prayer meeting. (57)

No mention was still made of who Godse was, and of his strong links with the RSS and the HM, particularly with its leader Savarkar. This was done, despite Sardar Patel, the then Home Minister's conclusion that it was a fanatical wing of HM directly under Savarkar that (hatched) the conspiracy and saw it through (Das 56). Also, while Savarkar was let off at the Gandhi Murder Trial for lack of corroborative evidence, he was severely indicted by the Kapur Commission set up in 1965 (Kapur Commission Report 303, par. 25.106).

While the Communist slogan of yeh azaadi jhooti hai (this freedom is false) is a fact well advertised, especially by Hindu communalists, a veil seems to have been drawn over the fact that the HM had declared $15^{\text {th }}$ August a day of mourning. Clearly, those who were on the other side of the barricades when the struggle against imperialism was enjoined do not want to be reminded of their past.

Today the communal regime in power pursues a strategy of selective appropriation of nationalist icons, this being particularly important to a political formation that espoused loyalism and did not stand on the side of the nation during the national movement. Along with Gandhi, to whom lip service is being paid, the Congress leader Vallabhbhai Patel is set up as a counterpoise to the much-maligned 
Nehru. Patel's birthday is observed on $31^{\text {st }}$ October as National Unity Day, while the late Prime Minister and Nehru's daughter, Indira Gandhi's birthday on the same day is ignored.

Gandhi has been reduced to a mascot for the present government's swachh abhiyaan (cleanliness campaign), his iconic glasses the logo, splashed across all billboards. Appropriating Gandhi is a travesty by a party distinguished by its absence from the annals of the national movement, whose earlier avatars, the HM, were directly involved in his assassination, which they tellingly termed asuravadh, slaying of a demon, rather than shahadat.

The three leaders, Gandhi, Nehru and Patel, with their different political styles, were united in their sturdy fight against imperialism and communalism. Dividing their legacy and selectively appropriating them is clearly part of a political agenda, unsupported by the historical record. It exposes the hollow or pseudo nationalism of the wannabe nationalists.

Reviews sent to author: 13 November 2017 Revised paper accepted for publication: 2 February 2018 


\section{REFERENCES}

"Allow Shiv Puja or Ban Friday Namaaz at Taj Mahal, Demands RSS History Wing." Outlook, 27 October 2017. https://www.outlookindia.com/website/story/allow-shiv-puja-or-ban-fridaynamaaz-at-taj-mahal-demands-rss-history-wing/303549. Accessed 15 December 2017.

"Bhagat Singh Dow: Case Filed Against the Book's Authors and DU Vic Chancellor." India Today, 1 May 2016. https://www.indiatoday.in/education-today/news/story/bhagat-singhrow-320992-2016-05-01. Acccessed 2 March 2018.

“Demonising Christianity and Islam.” In Communalism Combat, October 1999. Also see http:// www.sabrang. com/cc/comold/oct99.

"Fascist Attack on History and Secular Historians in India." In South Asia Documents. http://www. indowindow.com/sad/article.php?child=47\&amp;article=12. Accessed 2 March 2018.

"Former Panchjanya Editor is New NBT chief." Business Standard, 2 March 2015. http://www.businessstandard.com/article/politics/former-panchjanya-editor-is-new-nbt-chief-115030201303_1. html Accessed on 15 December 2017.

“Gaurav Gatha for Class Iv.” Saraswati Shishu Mandir Prakashan, Lucknow, 1992, pp. 30-31, 51-52.

“Itihas Gaa Rahaa Hai, Class v.” Saraswati Shishu Mandir Prakashan, Lucknow, 1991, p. 3.

“On Fascism and Nazism." In Communalism Combat, October 1999. Also see http://www.sabrang. com/cc/comold/oct99.

"Penguin Agrees to Axe Wendy Doniger's Controversial Book The Hindus: An Alternative History." India Today, 11 February 2014. https://www.indiatoday.intoday.in/story/wendy-donigerthe-hindus-alternative-history-penguin-scrapped/1/342913.html. Acccessed 2 March 2018.

BharatiYa Shikshan Mandal. http://www.bsmbharat.org/. Accessed 15 December 2017.

Bhatт, Cheta. Hindu Nationalism: Origins, Ideologies and Modern Myths. Bloomsbury, 2001.

Bhishikar, Keshav. Sangh Nirmata, Suruchi Sahitya Prakashan, 1979.

Chandra, Bipan, Mridula Mukherjee, Aditya Mukherjee, K.N. Panikkar and Sucheta Mahajan. India's Struggle for Independence. Penguin 1988.

Das, Durga. Sardar Patel Correspondence, 1945-50. Navajivan Publishing House, 1971-74,

Golwalkar, M.S. Bunch of Thoughts. Nd., 1966.

We or Our Nationhood Defined. Nagpur 1947 [1939].

Goyal, Desh Raj. Rashtriya Swayamsevak Sangh. South Asia Books, 2000.

Habib, Irfan, Suvira Jaiswal and Aditya Mukherjee. History in the NCERT Textbooks: A Report and an Index of Errors, Indian History Congress, 2003.

Hansen, Thomas Blom. The Saffron Wave: Democracy and Hindu Nationalism in Modern India. Princeton University Press, 1999.

Kanungo, Pralay. RSS Tryst with Politics from Hedgewar to Sudarshan. Manohar, 2002.

Kapur Commission Report. Jeevan Lal Kapur, Report of Commission of Inquiry into Conspiracy to Murder Mahatma Gandhi. New Delhi, 1970.

Mahajan, Sucheta, Mridula Mukherjee and Aditya Mukherjee. RSS, School Texts and the Murder of Mahatma Gandhi: The Hindu Communal Project. Sage, 2008. 
Mukherjee, Mridula and Aditya Mukherjee. Communalisation of Education: The History Textbooks Controversy. Delhi Historians' Group, 2002.

Pandey, Neelam. "Ram Setu a Man-made structure or Natural? Historical Research Council to Explore." Hindustan Times, 24 March 2017. http://www.hindustantimes.com/india-news/ ram-setu-a-man-made-structure-or-natural-ichr-to-explore/story-T9AtcmeKTvM6HVmIT5ulMO.html. Accessed 2 March 2018.

Savarkar, Vinayak Damodar. Hindutva: Who Is a Hindu? S.S. Savarkar 1969 [1923].

Sundar, Nandini. “Teaching to Hate: RSS’ Pedagogical Programme," Economic and Political Weekly, April 17, 2004.

Thapar, Romila. "Hindutva and History," Frontline, 17:20, Sep. 30-Oct. 13, 2000. http://www. frontline.in/arts-and-culture/heritage/hindutva-and-history/article6805140.ece. Accessed 2 March 2018. 
